\title{
Nutritivna vrijednost i antioksidacijska aktivnost jestivih samoniklih gljiva Albatrellus pes-caprae i Armillaria mellea
}

\section{Sažetak}

Ovo istraživanje namijenjeno je određivanju prosječnog kemijskog sastava, udjela bioaktivnih spojeva $i$ antioksidacijske aktivnosti jestivih samoniklih gljiva Albarellus per-caprae i Armilaria mellea. Rezultati određivanja kemijskog sastava su pokazali da su gljive bogat izvor bjelančevina i ugljikohidrata te da imaju male količine masti, a dobar su izvor energije. Koncentracije pet bioaktivnih spojeva (askorbinska kiselina, b-karoten, likopen, ukupni fenoli i flavonoidi) određene su ekstrakcijom plodišta gljiva u vrućoj vodi i metanolu. Tri komplementarna kemijska ispitivanja; reducirajuća snaga, uklanjanje slobodnih radikala (DPPH) i sposobnost keliranja iona željeza korišteni su za određivanje antioksidacijskih svojstava ekstrakata. Najveće vrijednosti antioksidacijskog kapaciteta određene su u ekstraktima A. mellea s vrućom vodom (9,01 $\mu \mathrm{M}$ TE/g s.tv. u reducirajućoj snazi, 65\% u sposobnosti uklanjanja slobodnih radikala, i 85\% u sposobnosti keliranja). Vrijednosti EC50 za tri različita ispitivanja antioksidanta bile su između 1,63 mg/ $\mathrm{mL}$ i $6,86 \mathrm{mg} / \mathrm{mL}$. Zbog ovih karakteristika, jestive samonikle gljive A. per-caprae i A. mellea mogu biti dio dobro uravnotežene prehrane i izvor bioaktivnih sastojaka.

Ključne riječi: Albarellus per-caprae, Armilaria mellea, nutritivna vrijednost, bioaktivni sastojci, antioksidacijskaaktivnost

\section{Uvod}

Posljednjih se godina razvila višestruka otpornost patogenih mikroorganizama na lijekove zbog pretjerane upotrebe antibiotika. Takvo stanje je ponukalo znanstvenike da intenzivnije počnu istraživati nove bioaktivne supstancije iz kultiviranih i samoniklih jestivih gljiva (Turkoglu i sur., 2007). Gljive obiluju nutraceuticima koji su zaslužni za njihovu antioksidacijsku aktivnost. Osim farmakoloških značajki, gljive postaju sve važnije u našoj prehrani zbog svoje nutritivne vrijednosti, zahvaljujući visokom udjelu proteina i vlakana, te niskom udjelu masti i maloj energijskoj vrijednosti (Agahar-Murugkar i Subbulakshmi, 2005; Barros i sur., 2008a), no važno je istaknuti da nutritivne vrijednosti, odnosno kemijski sastav ovise o stadiju zrelosti gljiva i kulinarskoj obradi (Dikeman i sur., 2005). Istraživanja su pokazala da redovita konzumacija gljiva ili sastojaka izoliranih iz gljiva poboljšava zdravstveni status i zbog toga se gljive mogu smatrati funkcionalnom hranom (Chang i Buswell, 1996; Mau i sur., 2002a,b). Nakupljaju različite sekundarne metabolite, poput fenolnih spojeva, poliketida, terpena i steroida, koji im daju medicinsku i funkcionalnu vrijednost (Turkoglu i sur., 2007). Važno je napomenuti da nakupljanje i udjel ovih spojeva ovisi o načinu skladištenja, prerade i fazi zrelosti gljiva u vrijeme skupljanja (Barros i sur., 2007b).

Slobodni radikali nastaju i u normalnom i u patološkom staničnom metabolizmu, što pokazuje da je oksidacija nužna mnogim živim organizmima za proizvodnju energije potrebne za biološke procese. Slobodni radikali koji se oslobađaju tijekom oksidacijskog stresa izazivaju ozbiljna endogena oštećenja u biološkim sustavima (Cheung i sur., 2003). Ova su oštećenja često povezana s različitim degenerativnim bolestima i stanjima, kao što su karcinom, kardiovaskularne bolesti, pad imuno sustava, te čak i ubrzano starenje organizma (Kaur i Kapoor,

izv. prof. dr. sc. Sunčica Beluhan, Katja Cukon, mag. ing. biotechn., red. prof. dr. sc. Mirela Ivančíč Šantek, Sveučilište u Zagrebu Prehrambeno-biotehnološki fakultet, Pierottijeva 6, 10000 Zagreb, Hrvatska (sunbel@pbf.hr) Autor za korespondenciju: sunbel@pbf.hr 
2001). Slobodni radikali su visoko reaktivne molekule koje u svojoj strukturi imaju ne sparene elektrone, a mogu nastati kao posljedica zračenja ili kao sporedni produkti metaboličkih procesa. Gotovo svi organizmi su zaštićeni od oštećenja koja izazivaju slobodni radikali pomoću oksidacijskih enzima, kao što su superoksid dismutaza i katalaza, te kemijskih spojeva, kao što su askorbinska kiselina, karotenoidi, $\alpha$-tokoferol, polifenolni spojevi i glutation. No, ti su obrambeni sustavi često nedostatni za potpunu prevenciju oštećenja koju izazivaju slobodni radikali, što u konačnici rezultira raznim bolestima i ubrzanim starenjem stanica.

U ovom su radu proučavani kemijski sastav i antioksidacijska svojstva dvije samonikle gljive, maglena (Albatrellus pes-caprae) i puze (Armillaria mellea). Istraživanja su bila podijeljena i provedena u četiri faze kako bi se: 1) odredio prosječni kemijski sastav gljiva (udjel suhe tvari, proteina, ukupnih šećera, masti i pepela) te njihova energijska vrijednost, 2) usporedio prinos ekstrakta iz gljiva nakon ekstrakcije $s$ dva ekstrakcijska sredstva; vrućom vodom i metanolom i 3) provela ekstrakcija bioaktivnih sastojaka (askorbinska kiselina, $\beta$-karoten, likopen, ukupni fenoli i flavonoidi), i 4) istražila antioksidacijska aktivnost gljiva spektrofotometrijskim metodama (redukcijska snaga, sposobnost uklanjanja slobodnih radikala, kapacitet vezanja iona željeza) $\mathrm{i}$ $\mathrm{EC}_{50}$ vrijednost uzoraka.

\section{Materijali i metode}

\section{Uzorci gljiva}

Uzorci samoniklih gljiva A. pes-caprae i $A$. mellea nabavljeni su na tržnici Dolac u Zagrebu u rujnu 2018. godine. Svježi uzorci su odmah izvagani, izrezani i stavljeni u suhi sterilizator (Instrumentaria, ST-05, 50-200 ㅇ. , Hrvatska) na sušenje $6 \mathrm{~h}$ pri $50 \stackrel{\circ}{ } \mathrm{C}$.

\section{Kemijski sastav gljiva}

Kemijski sastav gljiva određivan je mjerenjem suhe tvari, ukupnih proteina, ukupnih šećera, masti i pepela prema AOAC metodama (2012). Uzorci gljiva su nakon sušenja usitnjeni u tarioniku i kao takvi uporabljeni u svim određivanjima.

Suha tvar gljiva određivana je sušenjem gljiva do konstantne mase pri $105^{\circ} \mathrm{C} / 24 \mathrm{~h}$. Nakon hlađenja u eksikatoru, uzorci su izvagani, te je izračunata suha tvar u svakom uzorku (Alvarez i Enriquez, 1988). Količina ukupnih proteina u uzorcima gljiva određivana je metodom po Kjeldahlu. Za izračunavanje količine ukupnih proteina u uzorcima gljiva, određeni udjel dušika je množen faktorom 4,38 (Leon-Guzman i sur., 1997). Količina masti u uzorcima gljiva određivana je po Soxhletu, a.udjel pepela u uzorcima spaljivanjem u muflonskoj peći pri $550{ }^{\circ} \mathrm{C}$ tijekom $6 \mathrm{~h}$. Udjel ukupnih šećera izračunat je prema jednadžbi (Barros i sur., 2007a):

Ukupni šećeri $(g)=100-($ voda - proteini - masti - pepeo $)$

Ukupna energijska vrijednost je izračunata prema jednadžbi:

Energijska vrijednost $(\mathrm{kJ})=17 \times$ (g proteina $-\mathrm{g}$ šećera $)+37 \times$ (g masti)

\section{Ekstrakcija bioaktivnih sastojaka}

\section{1) Ekstrakcija vrućom vodom}

$1,5 \mathrm{~g}$ osušenih gljiva odvagano je s točnošću $\pm 0,1 \mathrm{~g}$ i homogenizirano s $20 \mathrm{~mL}$ zagrijane demineralizirane vode $(50 \stackrel{\circ}{\circ})$. Homogena smjesa ekstrahirana je 10 minuta pri temperaturi oko $90-95{ }^{\circ} \mathrm{C}$ uz povratno hladilo. Dobiveni ekstrakt je filtriran kroz filtar papir, a zaostali talog ponovno je ekstrahiran s $20 \mathrm{~mL}$ demineralizirane vode uz povratno hladilo još 10 minuta. Dobiveni ekstrakti su spojeni u odmjernoj tikvici od $50 \mathrm{~mL}$ i nadopunjeni vodom do oznake. 


\section{2) Ekstrakcija metanolom}

1,5 g osušenih gljiva odvagano je s točnošću $\pm 0,1 \mathrm{~g}$ i homogenizirano s $20 \mathrm{~mL}$ metanola $\left(95 \%, 25^{\circ} \mathrm{C}\right)$. Homogena smjesa ekstrahirana je 180 minuta pri $37^{\circ} \mathrm{C}$ na magnetnoj mješalici (250 okr/min). Dobiveni ekstrakt je filtriran kroz filtar papir, a zaostali talog ponovno je ekstrahiran s $20 \mathrm{~mL}$ metanola još 60 minuta. Dobiveni ekstrakti su spojeni u odmjernoj tikvici od 50 $\mathrm{mL}$ i nadopunjeni vodom do oznake.

\section{Određivanje bioaktivnih sastojaka}

\section{Ukupnifenoli}

Fenolni spojevi (flavonoidi) određivani su metodom prema Barros i sur. (2008a), uz manje modifikacije. $U$ epruvetu je otpipetirano $1 \mathrm{~mL}$ ekstrakta i $1 \mathrm{~mL}$ Folin-Ciocalteau reagensa, nakon čega je smjesa homogenizirana na vibromikseru. Nakon 3 minute je reakcijskoj smjesi dodano $1 \mathrm{~mL}$ zasićene otopine $\mathrm{Na}_{2} \mathrm{CO}_{3}$. Uzorak je stavljen na mračno mjesto 90 minuta, nakon čega je mjerena apsorbancija pri $725 \mathrm{~nm}$ (Unicam He $i$ ios $\lambda$, SAD). Na isti način je pripremljena i slijepa proba, ali je umjesto ekstrakta stavljena demineralizirana voda. Baždarni dijagram je izrađen s galnom kiselinom (0,01-0,4 mM; $\left.R^{2}=0,9989\right)$. Rezultati (mg GAE/g ekstrakta gljiva) su izračunati prema jednadžbi:

$$
y=2,8557 \cdot x-0,0021
$$

\section{Flavonoidi}

Fenolni spojevi određivani su metodom prema Pereira i sur. (2012), uz manje modifikacije. $250 \mu \mathrm{L}$ ekstrakta je pomiješano s $1,25 \mathrm{~mL}$ destilirane vode i $75 \mu \mathrm{L}$ \% Nakon 5 minuta, u reakcijsku smjesu je dodano $150 \mu \mathrm{L} 10 \%$-tne otopine $\mathrm{AlCl}_{3} \cdot \mathrm{H}_{2} \mathrm{O}$ i promiješano na vibracijskoj mješalici. Nakon 6 minuta je dodano $500 \mu \mathrm{L} 1 \mathrm{M} \mathrm{NaOH}$ i $275 \mu \mathrm{L}$ destilirane vode, te je reakcijska smjesa ponovno dobro promiješana na vibracijskoj mješalici. Intenzitet ružičaste boje je mjeren pri $510 \mathrm{~nm}$ (Unicam Heגios $\varepsilon$, SAD). Baždarni dijagram je izrađen $\mathrm{s}$ (+)-katehinom $\left(0,022-0,34 \mathrm{mM} ; \mathrm{R}^{2}=0,9998\right)$. Rezultati (mg CE/g ekstrakta gljiva) su izračunati premajednadžbi:

$$
y=0,9629 \cdot x-0,0002
$$

\section{Askorbinska kiselina}

Askorbinska kiselina je određivana prema metodi Vaz i sur. (2011). 150 mg osušenih gljiva je ekstrahirano s $10 \mathrm{~mL} 1 \%$ (tež/vol) metafosforne kiseline tijekom 45 minuta na sobnoj temperaturi, uz stalno miješanje. Nakon toga su uzorci filtrirani kroz filtar papir, a filtrati (1 mL) su pomiješani s $9 \mathrm{~mL}$ 2,6-dikloroindofenola. Uzorci su ostavljeni 30 minuta na sobnoj temperaturi, nakon čega im je mjerena apsorbancija na $515 \mathrm{~nm}$. Koncentracija askorbinske kiseline je izračunata prema baždarnom pravcu dobivenom mjerenjem apsorbancije pripadajućih koncentracija L-askorbinske kiseline $\left(0 ., 50-2,01 \mu \mathrm{g} / \mathrm{mL} ; \mathrm{R}^{2}=0,9969\right)$. Rezultati (mg L-askorbinske kiseline/100 g s. tv.) su izračunati prema jednadžbi:

$$
y=3,4127 \cdot x-0,0072
$$

\section{$\boldsymbol{\beta}$-karoten i likopen}

$\beta$-karoten (provitamin A) i likopen su određivani prema metodi Barros i sur. (2008a). 100 mg osušenih gljiva je homogenizirano s $10 \mathrm{~mL}$ smjese otapala aceton-heksan (4:6), uz snažno miješanje na vibromikseru. Uzorci su filtrirani kroz filtar papir, a nakon toga je filtratima mjerena apsorbancija na 453, 505 i 663 nm. Koncentracije $\beta$-karotena i likopena su izračunate prema jednadžbama: 
$\beta$-karoten $(\mathrm{mg} / 100 \mathrm{~mL})=0.216 \cdot \mathrm{A}_{663}-0.304 \cdot \mathrm{A}_{505}+0.452 \cdot \mathrm{A}_{453}$
likopen $(\mathrm{mg} / 100 \mathrm{~mL})=-0.0458 \cdot \mathrm{A}_{663}+0.372 \cdot \mathrm{A}_{505}-0.0806 \cdot \mathrm{A}_{453}$

likopen $(\mathrm{mg} / 100 \mathrm{~mL})=-0.0458 \cdot A_{663}+0.372 \cdot A_{505}-0.0806 \cdot A_{453}$

\section{Određivanjeantioksidacijskeaktivnosti}

\section{Reducirajućasnaga}

Reducirajuća snaga je određivana prema metodi Gulçin i sur. (2003). Svaki od ekstrakata $(0,1-7,0 \mathrm{mg} / \mathrm{mL})$ je pomiješan s 2,5 mL $200 \mathrm{mM}$ fosfatnog pufera $(\mathrm{pH} \mathrm{6,6)} \mathrm{i} \mathrm{2,5} \mathrm{mL} \mathrm{kalijevog}$ ferocijanida (10 mg/mL), te inkubiran pri $50^{\circ} \mathrm{C}$ tijekom 20 minuta. Nakon toga je u uzorke dodano $2,5 \mathrm{~mL}$ trikloroctene kiseline $(100 \mathrm{mg} / \mathrm{mL})$ i centrifugirani su pri $200 \mathrm{~g} / 10$ minuta. Gornji sloj $(5 \mathrm{~mL})$ je pomiješan $\mathrm{s} 5 \mathrm{~mL}$ deionizirane vode i $1 \mathrm{~mL}$ željeznog klorida $(1 \mathrm{mg} / \mathrm{mL})$, te je izmjerena apsorbancija na $700 \mathrm{~nm}$. Veća vrijednost apsorbancije ukazala je na veću reducirajuću snagu. $\mathrm{EC}_{50}$ vrijednosti (mg ekstrakta/mL) su koncentracije ekstrakta pri kojima je apsorbancija iznosila $1 / 2$ vrijednosti apsorbancije izmjerene za reducirajuću snagu i dobivene su interpolacijom. Kao standard je uporabljen Trolox, a rezultati su izraženi kao $\mu \mathrm{M}$ Trolox ekvivalenata (TE)/g s. tv. ekstrakta.

\section{Uklanjanje slobodnih radikala DPPH metodom}

Antioksidacijska aktivnost uzoraka određena je mjerenjem sposobnosti inhibicije slobodnog 2,2-difenil-1-pikrilhidrazil (DPPH) radikala. Antioksidacijska sposobnost se mjeri u vidu otpuštanja vodika iz antioksidanta, odnosno sposobnosti vezanja radikala pri čemu se koristi stabilni DPPH radikal (Cheung i sur., 2003). Postotak inhibicije DPPH radikala uzoraka računat je prema jednadžbi:

$\%$ inhibicije $=\left[1-\left(A_{\text {uzorka }}-A_{0}\right)\right] \cdot 100$

$A_{\text {uzorka }}$ - apsorbancija istraživanog uzorka na $517 \mathrm{~nm}$

$A_{0}$ - apsorbancija slijepe probe na $517 \mathrm{~nm}$

\section{Sposobnost vezanja iona željeza}

Sposobnost vezanja iona željeza određivana je prema metodi Soares i sur. (2009) uz male izmjene. Svaki od ekstrakata $(0,1-7 \mathrm{mg} / \mathrm{mL})$ je razrijeđen $\mathrm{s} 0,7 \mathrm{~mL}$ demineralizirane vode $i$ pomiješan s 0,175 $\mathrm{mL} \mathrm{0,5} \mathrm{mM}$ željeznog klorida. Reakcija je pokrenuta dodatkom $0,175 \mathrm{~mL} \mathrm{0,5}$ $\mathrm{mM}$ ferozina i izmjerena je početna vrijednost apsorbancije na $550 \mathrm{~nm}$. Nakon inkubacije na sobnoj temperaturi (10 minuta), ponovno je izmjerena apsorbancija na $550 \mathrm{~nm}$. Niža vrijednost apsorbancije ukazuje na veću sposobnost vezanja. Postotak vezanja ferozin-Fe ${ }^{2+}$ kompleksa izračunat je prema jednadžbi:

Sposobnost keliranja $(\%)=\left[\left(A_{0}-A_{1}\right) / A_{0}\right] \cdot 100$

$A_{0}$ - početna vrijednost apsorbancije na $550 \mathrm{~nm}$

$A_{1}$ - vrijednost apsorbancije na $550 \mathrm{~nm}$ nakon 10 minuta inkubacije

\section{Rezultati i rasprava}

$\mathrm{U}$ ovom radu je određivan prosječan kemijski sastav i antioksidacijska aktivnost ekstrakata dvije samonikle jestive gljive $A$. pes-caprae i $A$. mellea. U vrijeme prikupljanja gljiva, vrijeme je bilo suho i stabilno, što je utjecalo na udjel suhe tvari, budući da je znano da udjel vlage u gljivama ovisi o vremenskim uvjetima koji su prethodili prikupljanju. Sva istraživana su provedena na uzorcima plodišta A. pes-caprae i A. mellea (Slika 1). 
a

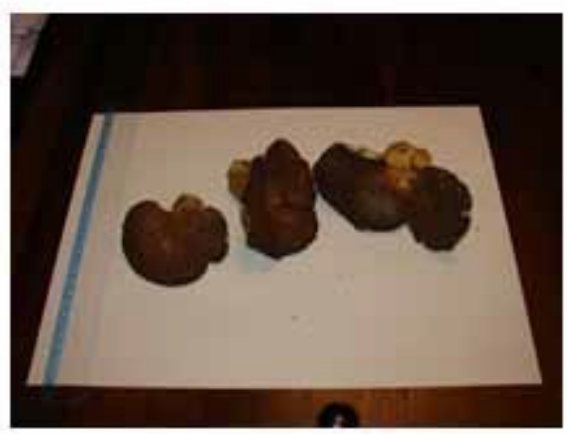

b

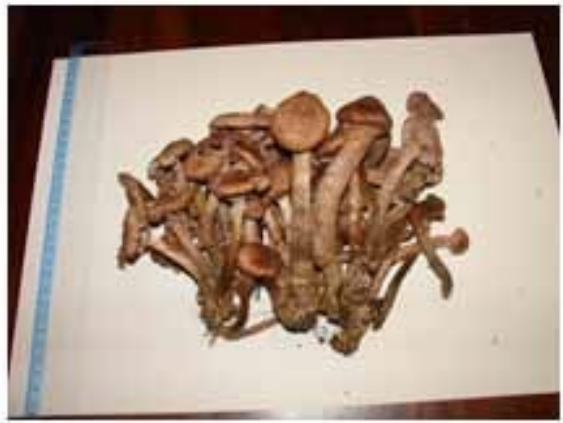

Slika 1. Fotografije istraživanih vrsta gljiva: a) A. pes-caprae; b) A. mellea

Fig. 1. Photographs of investigated mushroom species: a) A. pes-caprae; b) A. mellea

\section{Nutritivna vrijednost i kemijski sastav gljiva}

Jedan od glavnih zahtjeva pri odabiru prehrambene namirnice je njezina nutritivna vrijednost. Kada se radi o samoniklim gljivama, nutritivni se sastojci izračunavaju u odnosu na suhu tvar, jer je poznato da gljive imaju visok udjel vode, posebice u kišnim dijelovima godine, koji utječu, ne samo na teksturu, nego i na relativno kratko vrijeme održavanja te namirnice (Kalač, 2009). Rezultati ovih istraživanja pokazali su da je manju prosječnu vrijednost udjela suhe tvari imala A. pes-caprae 8,21 \%, dok je kod A. mellea izmjereno 11,29 \% (Tablica 1). Prema nutritivnim kriterijima, plodišta gljiva su bogat izvor proteina i ugljikohidrata. Prema Colaku i sur. (2009), udjel proteina u samoniklim gljivama izravno je povezan s porodicom, odnosno određenom vrstom gljiva i njihovoj fazi zrelosti u vrijeme prikupljanja, te koncentraciji dušika u tlu na kojem su rasle. Ugljikohidrati predstavljaju sastojak koji je u najvećem udjelu zastupljen u gljivama. Gukoza, manitol i trehaloza su zastupljeni u najvećim koncentracijama. Udjel ugljikohidrata mijenja se ovisno o načinu skladištenja i obrade. Prema rezultatima istraživanja, udjel trehaloze i manitola se znatno smanjuje tijekom termičke obrade svježih plodišta gljiva, dok se sušenjem ili zamrzavanjem taj udjel tek neznatno smanjuje (Barros i sur., 2007a). Istraživanja u ovom radu su pokazala da je udjel proteina i ugljikohidrata u A. pes-caprae bio 4,43\% i 6,93, a u $A$. mellea $1,64 \%$, i 7,15 \%. Spojevi koji čine ukupne masti mogu se podijeliti na slobodne masne kiseline, tri- di- i monogliceride, fosfolipide, te sterole. Gljive se mogu konzumirati kao namirnice s malim udjelom masti, kao što je izmjereno u pokusima. Udjel masti u $A$. pes-caprae bio je $0,23 \%$, a u $A$. mellea $0,18 \%$, što su najniže izmjerene vrijednosti u cijelom kemijskom sastavu istraživanih gljiva. Maseni udjel pepela u analiziranim gljivama bio je $0,51 \%(A$. pescaprae) i 0,56 \% (A. mellea). Prema Mattila i sur. (2001), glavni sastojci pepela su K i P (60 \%), tako da se njihovim malim udjelom može objasniti mala koncentracija pepela $u$ istraživanim gljivama, iako u ovom radu nisu određivani. $U$ ovom su istraživanju određene niske energijske vrijednosti gljiva $A$. per-caprae (201,62 kJ/100 g s.tv.) i A. mellea (200,09 kJ/100 g s.tv) (Tablica 1). Colak i sur. (2009) su odredili vrijednosti od 155 kJ/100 g s. tv. za Amanita rubensces i $259 \mathrm{~kJ} / 100$ g s. tv. za Lepista nuda, tako da se rezultati dobiveni u ovom radu mogu smatrati usporedivim jer je u drugom istraživanju određena puno manja energijska vrijednost $(87,3 \mathrm{~kJ} / 100 \mathrm{~g} \mathrm{~s}$. tv. za Lepista nuda) (Barros i sur., 2007a). Energijska vrijednost ovisi o vlažnosti uzoraka i udjelu ugljikohidrata, najčešće manitola i hitina (nisu određivani), koji su djelomično probavljivi ili neprobavljivi (Kalač, 2009). 
Tablica 1. Prosječni kemijski sastav (g/100 g) i energijska vrijednost (kJ/100 g) plodišta $A$. pes-caprae i A. mellea

Table 1. Proximate chemical composition (g/100 g) and energy value (kJ/100 g) of $A$. pescaprae and $A$. mellea fruit bodies

\begin{tabular}{|c|c|c|c|c|c|c|}
\hline $\begin{array}{l}\text { Vrsta gljiva/ } \\
\text { Mushroom } \\
\text { species }\end{array}$ & $\begin{array}{l}\text { Suha tvar } \\
\text { (\%)/Dry } \\
\text { weight (\%) }\end{array}$ & $\begin{array}{l}\text { Proteini } \\
\text { (g/100 g)/ } \\
\text { Proteins } \\
\text { (g/100 g) }\end{array}$ & $\begin{array}{c}\text { Šećeri (g/100 } \\
\text { g) } \\
\text { /Sugars } \\
\text { (g/100g) }\end{array}$ & $\begin{array}{c}\text { Masti (g/100 } \\
\text { g) } \\
\text { /Fat } \\
\text { (g/100g) }\end{array}$ & $\begin{array}{c}\text { Pepeo (g/100 } \\
\text { g) } \\
/ \text { Ash } \\
\text { (g/100g) }\end{array}$ & $\begin{array}{c}\text { Energija } \\
\text { (kJ/100g) } \\
\text { /Energy } \\
\text { (g/100g) }\end{array}$ \\
\hline A. pes-caprae & 8,21 & 4,43 & 6,93 & 0,23 & 0,51 & 201,62 \\
\hline A. mellea & 11,29 & 3,64 & 7,15 & 0,18 & 0,56 & 200,09 \\
\hline
\end{tabular}

Rezultati su izraženi na suhu tvar (s. tv.) / Results are expressed in a dry weight (d. w.) basis.

Za ekstrakciju malih molekula iz gljiva najčešće se kao ekstrakcijsko otapalo koristi metanol (Mau i sur., 2002a; Vaz i sur., 2011). Neka su istraživanja pokazala da različite bioaktivne molekule, posebice fenolni spojevi koje nalazimo u gljivama, pokazuju visoku polarnost (Jayakumar i sur., 2011; Wong i Chye, 2009). U ovom radu je ekstrakcija bioaktivnih sastojaka provedena s dva ekstrakcijska sredstva, vrućom vodom i metanolom, s ciljem dobivanja ekstrakata sa spojevima velike molekulske mase, kao što su polisaharidi i male molekulske mase, koji su većinom fenolni spojevi. Obje vrste spojeva imaju važnu ulogu u nutricionističkom i medicinskom statusu gljiva (Ferreira i sur., 2010). Prinos ekstrakata iz uzoraka ispitivanih gljiva prikazan je u Tablici 2. Kako se može uočiti, ekstrakcijom vrućom vodom i metanolom, i kod jedne i druge gljive, postignuti su podjednaki rezultati. Prinos ekstrakta je bio veći u vodenom ekstraktu $A$. pescaprae (41,12\%), dok je u metanolnom ekstraktu određen dvostruko manji prinos (18,09\%). Slični odnos dobivenih rezultata uočen je i u ekstraktima $A$. mellea; u vodenom $39,66 \%$, te dva puta manji prinos u metanolnom ekstraktu (16,12 \%). Dobiveni rezultati mogu se usporediti s rezultatima Tsai i sur. (2009) i Vaz i sur. (2011), koji su pripravljali ekstrakte pet, odnosno četiri vrste samoniklih gljiva s vrućom vodom i etanolom, te su prema dobivenim prinosima zaključili da je ekstrakcija vrućom vodom učinkovitija od ekstrakcije etanolom. Primjena vruće vode za ekstrakciju topljivih sastojaka poslužila je za simulaciju dobivanja pripravaka koji se uporabljaju u kineskoj medicini i pripravljanja biljnih čajeva koji imaju ljekovita svojstva. U usporedbi s ekstrakcijom metanolom kao otapalom, dobivene informacije o uspješnosti ekstrakcije s vrućom vodom mogle bi biti vrijedne za pripravu ekstrakata koji se koriste u ljudskoj prehrani.

Tablica 2. Prinos ekstrakta plodišta $A$. pes-caprae i $A$. mellea nakon ekstrakcije vrućom vodom i metanolom

Table 2. Extraction yield of hot water and methanolic extracts from A. pes-caprae and $A$. mellea fruit bodies

\begin{tabular}{lcc}
\hline \multirow{2}{*}{ Vrsta gljiva/Mushroom species } & \multicolumn{2}{c}{$\begin{array}{c}\text { Prinos ekstrakta iz gljiva (g/100 g s. tv.)/ } \\
\text { Mushroom extract yield (g/100 g dry matter) }\end{array}$} \\
\cline { 2 - 3 } A. pes-caprae & $\begin{array}{c}\text { Vruća voda/ } \\
\text { Hot water }\end{array}$ & $\begin{array}{c}\text { Metanol/ } \\
\text { Methanol }\end{array}$ \\
\hline A. mellea & 41,12 & 18,09 \\
\hline
\end{tabular}

Rezultati su izraženi na suhu tvar ekstrakta (s. tv.) / Results are expressed in a dry extract weight (d. w.) basis. 
Povrće, voće i gljive su bogati izvori bioaktivnih spojeva, kao što su vitamini A, C i E, karotenoidi, polifenolne supstancije i flavanoidi, koji štite od oštećenja slobodnim radikalima, te smanjuju rizik od kroničnih bolesti (Barros i sur., 2008b). U ovom radu jedan od ciljeva bio je ispitati udjel tih spojeva $u$ istraživanim gljivama, odnosno odrediti udjel askorbinske kiseline, $\beta$-karotena, $\alpha$-tokoferola, ukupnih fenola i flavonoida, a rezultati su prikazani u Tablici 3. Kako se može vidjeti iz tablice, askorbinska kiselina je u malim koncentracijama određena u oba ekstrakta istraživanih gljiva, pri čemu je u vodenim ekstraktima bila podjednaka $(0,17$ i 0,15 $\mathrm{mg} / \mathrm{g}$ s. tv.). U metanolnim ekstraktima određena je tri puta veća koncentracija $(0,66$ i 0,41 $\mathrm{mg} / \mathrm{g}$ s. tv.). U vodenom ekstraktu nije određen udjel $\beta$-karotena jer nije topljiv u vodi, no i u metanolnim ekstraktima je izmjeren u vrlo malim koncentracijama $(0,04$ i 0,07 mg/g s. tv). Udjel likopena je također izmjeren u vrlo malim koncentracijama (od 0,01 do 0,05 mg/g). Ovi su rezultati usporedivi s rezultatima Barros i sur. (2007a) i Tsai i sur. (2009), koji su također u vodenim, etanolnim i metanolnim ekstraktima više vrsta samoniklih gljiva odredili vrlo male koncentracije $\beta$-karotena i likopena (od 0,01 do 0,05 mg/g s.tv.). Istraživanja su pokazala da je antioksidacijska aktivnost ekstrakata bilja i gljiva izravno povezana s udjelom fenolnih sastojaka i flavonoida (Caprioli i sur., 2019). Nekoliko autora je istraživalo korelaciju između polarnosti ekstrakcijskog otapala i udjela fenolnih spojeva u dobivenim ekstraktima gljiva (Cheung i sur., 2003; Puttaraju i sur, 2006). Iz Tablice 3 je vidljivo da je veći udjel fenolnih sastojaka određen u vodenim ekstraktima gljiva; $A$. mellea $(32,86 \%)$, A. pes-caprae $(14,91 \%)$, dok je u metanolnim ekstraktima izmjerena skoro tri puta manja vrijednost; $A$. mellea $(12,61 \%)$, A. pes-caprae $(3,98$ $\%)$. Udjel flavonoida je slijedio udjel ukupnih fenola, no u dvostruko manjim koncentracijama, u vodenim ekstraktim gljiva $A$. mellea $(17,36 \%)$, A. pes-caprae $(7,82 \%)$, dok je u metanolnim ekstraktima izmjerena dva i pol puta manja vrijednost; $A$. mellea $(6,21 \%)$, A. pes-caprae $(2,11$ $\%)$. Dobiveni rezultati su u suglasju s nekoliko provedenih istraživanja, no nijedno od tih istraživanja nije provedeno na vrsti gljive $A$. pes-caprae, nego na brojnim drugim vrstama samoniklih gljiva, među kojima je i $A$. mellea (Ouzouni i sur., 2009; Wong i Chye, 2009; Vaz i sur., 2011).

Tablica 3. Udjeli bioaktivnih sastojaka u ekstraktima plodišta A. pes-caprae i $A$. mellea fruit bodies Table 3. Contents of bioactive compounds the $A$. pes-caprae i $A$. mellea extracts fruit bodies

\begin{tabular}{|c|c|c|c|c|c|}
\hline \multirow{3}{*}{$\begin{array}{l}\text { Vrste gljiva/ } \\
\text { Mushroom } \\
\text { species }\end{array}$} & \multicolumn{4}{|c|}{$\begin{array}{c}\text { Udjel (mg/g) } \\
\text { Contetnt (mg/g) }\end{array}$} & \multirow[b]{3}{*}{$\begin{array}{l}\text { 'Flavonoidi/ } \\
\text { 'Flavonoids }\end{array}$} \\
\hline & \multirow[b]{2}{*}{ 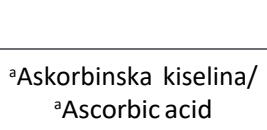 } & \multicolumn{2}{|c|}{ Vruća voda/Hot water } & \multirow[b]{2}{*}{$\begin{array}{l}\text { 'Ukupni fenoli/ } \\
\text { 'Total phenols }\end{array}$} & \\
\hline & & $\begin{array}{l}\text { a } \beta \text {-karoten/ } \\
\text { a } \beta \text {-carotene }\end{array}$ & $\begin{array}{l}\text { aLikopen/ } \\
\text { aLycopene }\end{array}$ & & \\
\hline A.pes-caprae & 0,17 & $\mathrm{no}^{\mathrm{d}} / \mathrm{nd}^{\mathrm{d}}$ & 0,05 & 14,91 & 17,82 \\
\hline A. mellea & 0,15 & no/nd & 0,02 & 32,86 & 17,16 \\
\hline \multicolumn{6}{|c|}{ Metanol/Methanol } \\
\hline A.pes-caprae & 0,66 & 0,04 & 0,02 & 3,98 & 2,11 \\
\hline A. mellea & 0,41 & 0,07 & 0,01 & 12,61 & 6,21 \\
\hline
\end{tabular}

${ }^{\mathrm{a}}$ Rezultati su izraženi na suhu tvar gljiva (s. tv.)/ ${ }^{\circ}$ Results are expressed in a mushrooms dry weight (d. w.) basis.

${ }^{\mathrm{b}}$ Rezultati su izraženi kao ekvivalent GAE po g ekstrakta (mg GAE/g)/ ${ }^{\mathrm{b}}$ Results are expressed as GAE equivalent in a $g$ of extract (mg GAE/g) basis.

'Rezultati su izraženi kao ekvivalent katehina po g ekstrakta (mg CE/g)/ ${ }^{\circ}$ Results are expressed as chatechin equivalent in a g of extract ( $\mathrm{mg} \mathrm{CE} / \mathrm{g}$ ) basis.

${ }^{\mathrm{d}}$ no $=$ nije određeno

${ }^{\mathrm{d}} \mathrm{nd}=$ not detected 
Sposobnost ekstrakta gljiva da doniraju elektrone može se evaluirati određivanjem reducirajuće snage. $U$ prisustvu antioksidanta, kompleks $\mathrm{Fe}^{3+}$-fericijanid se reducira do $\mathrm{Fe}^{2+} \mathrm{i}$ mjeri apsorbancija na $700 \mathrm{~nm}$, pri čemu veća vrijednost apsorbancije ukazuje na veću reducirajuću snagu (Puttaraju i sur., 2006). Sposobnost ekstrakata ispitivanih gljiva da reduciraju $\mathrm{Fe}^{3+}$ do $\mathrm{Fe}^{2+}$ pri različitim koncentracijama ekstrakta je prikazana na Grafikonu 1. Ekstrakti plodišta gljiva A. pes-caprae i $A$. mellea pokazali su različiti kapacitet redukcije, no općenito, ta je sposobnost linearno rasla s povećanjem koncentracije ekstrakta. Od svih uzoraka, vodeni ekstrakt $A$. mellea pokazao je najveći kapacitet za redukciju jer je od koncentracije $0,1 \mathrm{mg} / \mathrm{mL}$ do $2,4 \mathrm{mg} / \mathrm{mL}$, vrijednost izmjerene apsorbancije porasla s 0,051 na 0,605 , a pri koncentraciji od $6,4 \mathrm{mg} / \mathrm{mL}$ je izmjerena vrijednost bila 1.,09 i nakon te vrijednosti se nije mijenjala. Pri istim koncentracijama, u metanolnom ekstraktu $A$. mellea izmjerena je apsorbancija od 0,047 i 0,569, a najveća apsorbancija, 0,895 je izmjerena pri $7 \mathrm{mg} / \mathrm{mL}$ ekstrakta. I u vodenim i u metanolnim ekstraktima plodišta gljive $A$. pes-caprae također je primijećeno linearno povećanje apsorbancije. $U$ vodenom ekstraktu pri koncentracijama od $0,1 \mathrm{mg} / \mathrm{mL}$ do $2,4 \mathrm{mg} / \mathrm{L}$ vrijednosti $A_{700}$ su se kretale od 0,029 do 0,451 , dok je najveća izmjerena, također pri $7 \mathrm{mg} / \mathrm{mL}$ bila 0,859 . U metanolnom ekstraktu, pri istim koncentracijama, izmjerene $A_{700}$ vrijednosti bile su 0,021 i 0,352, a pri $7 \mathrm{mg} /$ $\mathrm{mL}$ izmjerena vrijednost bila 0,859. Kako se može uočiti iz Grafikona 1, svi ekstrakti plodišta gljiva su pokazali izvrsnu reducirajuću snagu. Dobiveni rezultati mogu se usporediti s rezultatima Sarikurkcu i sur. (2008) koji su istraživali reducirajuću snagu metanolnih ekstrakata četiri vrste samoniklih gljiva i pri koncentraciji od $2 \mathrm{mg} / \mathrm{mL}$ izmjerili vrijednosti $A_{700}$ u uzorcima od 0,284 do 0,574 . Bolji rezultati u ovom istraživanju postignuti su u usporedbi s rezultatima Huang (2000), koji je, istražujući reducirajuću snagu medicinske gljive Antrodia camphorata, izmjerio $A_{700}$ vrijednost vodenog ekstrakta 0,96-0,97 pri $10 \mathrm{mg} / \mathrm{mL}$ i zaključio da ta gljiva ima izvrsnu antioksidacijsku aktivnost.

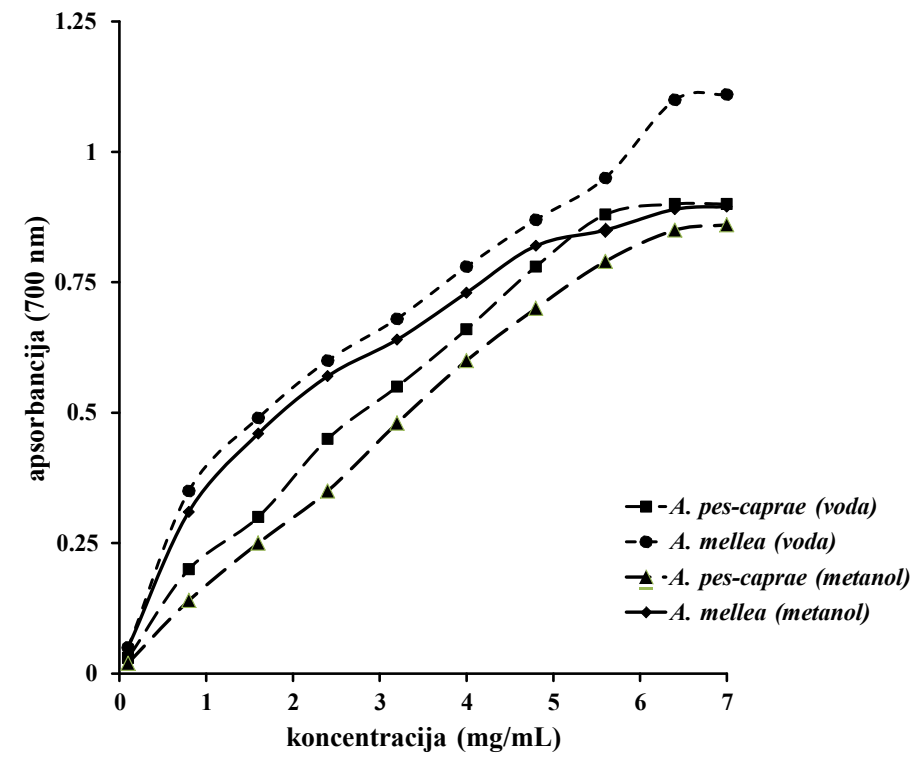

Grafikon 1. Reducirajuća snaga vodenih i metanolnih ekstrakata plodišta $A$. pes-caprae i $A$. mellea

Graph. 1. Reducing power of the A. pes-caprae and A. mellea fruit bodies water and methanolic extracts 
Smatra se da je reducirajuća snaga gljiva rezultat sposobnosti doniranja atoma vodika (Jayakumar i sur., 2011). Prema tome, A. mellea ima veći udjel reducensa koji mogu djelovati na slobodne radikale, stabilizirati ih i zaustaviti njihove lančane reakcije. Ukupna reducirajuća snaga izražena kao $\mu \mathrm{g}$ TE/g s.tv. prikazana je u Tablici 4. Sukladno izmjerenim vrijednostima $\mathrm{A}_{700}$, prikazanim u Grafikonu 2, u tablici je vidljivo da veću redukcijsku snagu ima $A$. mellea, i u vodenom i u metanolnom ekstraktu.

Tablica 4. Ukupna reducirajuća snaga ekstrakata plodišta $A$. pes-caprae i $A$. mellea

Table 4. Total reducing power of extracts from $A$. pes-caprae i $A$. mellea fruit bodies

\begin{tabular}{|c|c|c|}
\hline \multirow{2}{*}{$\begin{array}{l}\text { Vrsta gljiva/ } \\
\text { Mushroom species }\end{array}$} & \multicolumn{2}{|c|}{$\begin{array}{l}\text { Ukupna reducirajuća snaga ( } \mu \mathrm{g} \mathrm{TE} / \mathrm{g} \mathrm{s.} \text { tv.) } \\
\text { Total reducing power/ ( } \mu \mathrm{g} \mathrm{TE} / \mathrm{g} \text { d.w.) }\end{array}$} \\
\hline & Vruća voda/Hot water & Metanol/Methanol \\
\hline A.pes-caprae & $7,25^{b}$ & $7,05^{b}$ \\
\hline A. mellea & $9,01^{b}$ & $8,62^{b}$ \\
\hline
\end{tabular}

Prema reducirajućoj snazi, gljive su podijeljene u podgrupe: a-vrlo visoka = 10;

b-visoka = 5-10; c-srednja = 2.5-5; d-niska < $2.5 \mu \mathrm{g} \mathrm{TE} \mathrm{(Trolox)/g} \mathrm{s.} \mathrm{tv.}$

Reducing power of mushrooms was gruped as: a-very high = 10; b-high = 5-10; c-medium

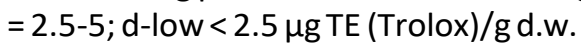

Jedna od najčešće korištenih metoda određivanje antioksidacijske aktivnosti uzoraka je metoda uklanjanja DPPH slobodnih radikala koja se temelji na redukciji metanolne DPPH otopine u prisutnosti sastojka koji donira vodik (antioksidanta). Rezultirajuće obezbojenje reakcijske smjese zbog apsorpcije vodika iz antioksidanta je stehiometrijska reakcija i rezultat je stupnja redukcije. Preostali DPPH, izmjeren nakon nekog vremena, korespondira obrnuto razmjerno sa sposobnosti uklanjanja radikala prisutnih u antioksidantu (Mau i sur., 2005; Lee i sur., 2007). Uklanjanje slobodnih radikala poznati je mehanizam kojim antioksidanti inhibiraju lipidnu oksidaciju. Metodom uklanjanja DPPH slobodnih radikala može se u kratkom vremenu procijeniti antioksidacijska aktivnost specifičnog sastojka ili ekstrakta (Oyetayo, 2009). Istraživanja su provedena s ekstraktima u koncentracijama od 0,1 do $7 \mathrm{mg} / \mathrm{mL}$. Kao što se moglo i očekivati, najmanje uklanjanje slobodnih DPPH radikala u svim ekstraktima izmjereno je pri koncentraciji od 0,1 mg/mL (od 0,3\% do 0,7 \%), a najveće kod najveće koncentracije, $7 \mathrm{mg} / \mathrm{mL}$ (od $51 \%$ do $65 \%)$. Pri tome je uočeno linearno povećanje sposobnosti uklanjanja DPPH radikala od najniže do najviše koncentracije (Grafikon 2). Vodeni ekstrakti plodišta A. pes-caprae i A. mellea pokazali su veću sposobnost uklanjanja slobodnih radikala od metanolnih ekstrakata. Pri koncentraciji od $7 \mathrm{mg} / \mathrm{mL}$, u vodenim ekstraktima je postignuto uklanjanje od $59 \%$ (A. pes-caprae) i $65 \%$ (A. mellea). U metanolnim ekstraktima je, pri istoj koncentraciji postignuto uklanjanje od $51 \%$ ( $A$. pes-caprae) i $59 \%$ (A. mellea). Bolja sposobnost uklanjanja DPPH slobodnih radikala određena je u vodenim ekstraktima u kojima je izmjerena visoka koncentracija ukupnih fenola (Tablica 3). Prema literaturnim navodima, a i rezultatima dobivenim ovim istraživanjem, i vodeni i metanolni ekstrakti sadrže biološki aktivne sastojke, koji posjeduju visoki kapacitet za doniranje vodika i uklanjanje slobodnih DPPH radikala, što ukazuje na njihovu antioksidacijsku aktivnost (Cheung i sur., 2003; Tsai i sur-. 2009; Oyeatayo, 2009). 


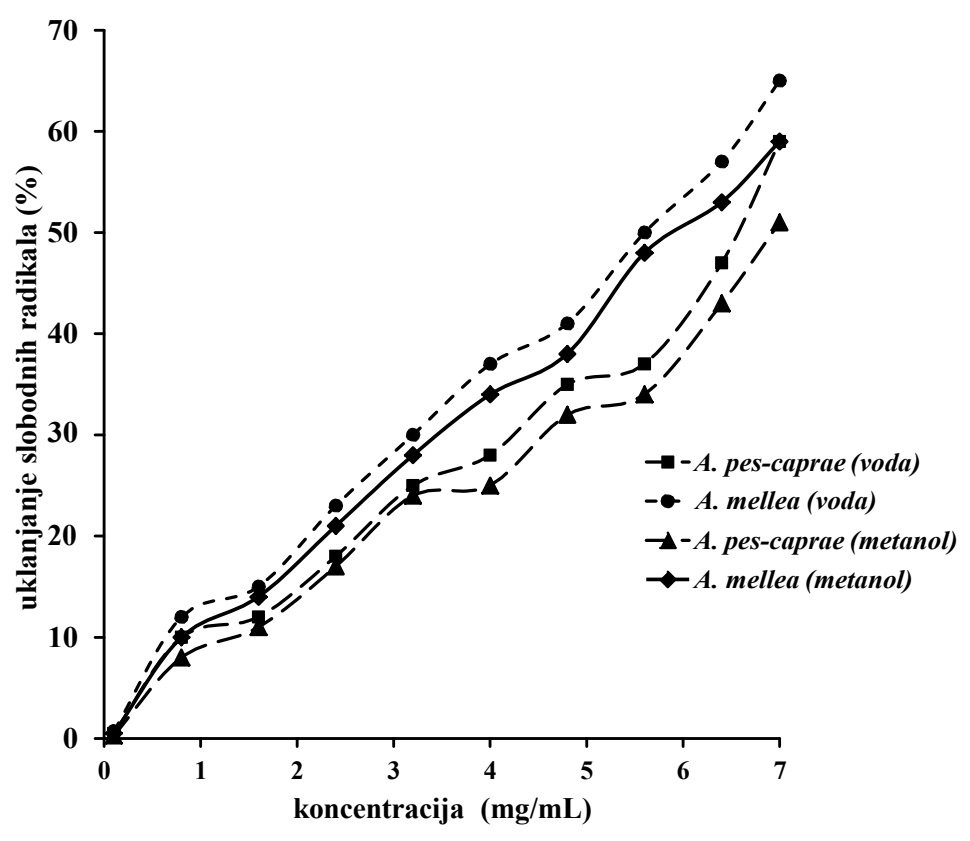

Grafikon 2. Uspješnost uklanjanja DPPH radikala vodenih i metanolnih ekstrakata plodišta A. pes-caprae i A. mellea

Graph. 2. Scavenging effects of the $A$. pes-caprae and $A$. mellea fruit bodies water and methanolic extracts on DPPH radicals

Raspon i sposobnost keliranja $\mathrm{Fe}^{2+}$ iona značajno varira među različitim vrstama gljiva. Željezo stimulira lipidnu peroksidaciju putem Fentonove reakcije i ubrzava peroksidaciju razgradnjom lipidnih hidroperoksida do peroksila i alkoksil radikala, koji mogu izazvati lančanu reakciju lipidne peroksidacije (Wang i Chye, 2009). Provedenim određivanjima sposobnosti keliranja $\mathrm{Fe}^{2+}$ iona, uočeno je da je ta sposobnost rasla s porastom koncentracije ekstrakta (Grafikon 3). Kao što se moglo i očekivati, najmanja sposobnost keliranja u svim ekstraktima izmjerena je pri najnižoj koncentraciji $(0,1 \mathrm{mg} / \mathrm{mL}$; od $2 \%$ do $7 \%)$, a najveće kod najveće koncentracije, $7 \mathrm{mg} /$ $\mathrm{mL}$ (od $70 \%$ do $85 \%$ ). Pri tome je uočeno eksponencijalno povećanje sposobnosti keliranja $\mathrm{Fe}^{2+}$ iona od $0,1 \mathrm{mg} / \mathrm{mL}$ do $2,4 \mathrm{mg} / \mathrm{mL}$, nakon čega je uslijedio linearni porast vrijednosti. Vodeni ekstrakti plodišta $A$. pes-caprae i $A$. mellea pokazali su veću sposobnost uklanjanja slobodnih radikala od metanolnih ekstrakata. Pri koncentraciji od $7 \mathrm{mg} / \mathrm{mL}$, u vodenim ekstraktima je postignuto uklanjanje od $79 \%$ (A. pes-caprae) i $85 \%$ (A. mellea). U metanolnim ekstraktima je, pri istoj koncentraciji postignuto uklanjanje od $74 \%$ (A. pes-caprae) i $70 \%$ (A. mellea).

Mora se istaknuti da za antioksidacijsku aktivnost ekstrakata gljiva nisu odgovorni samo fenolni spojevi. Nekoliko vrsta organskih kiselina su također reaktivne u različitim antioksidacijskim metodama, posebice kod metode istraživanja sposobnosti keliranja iona željeza (Valentão i sur., 2005). 


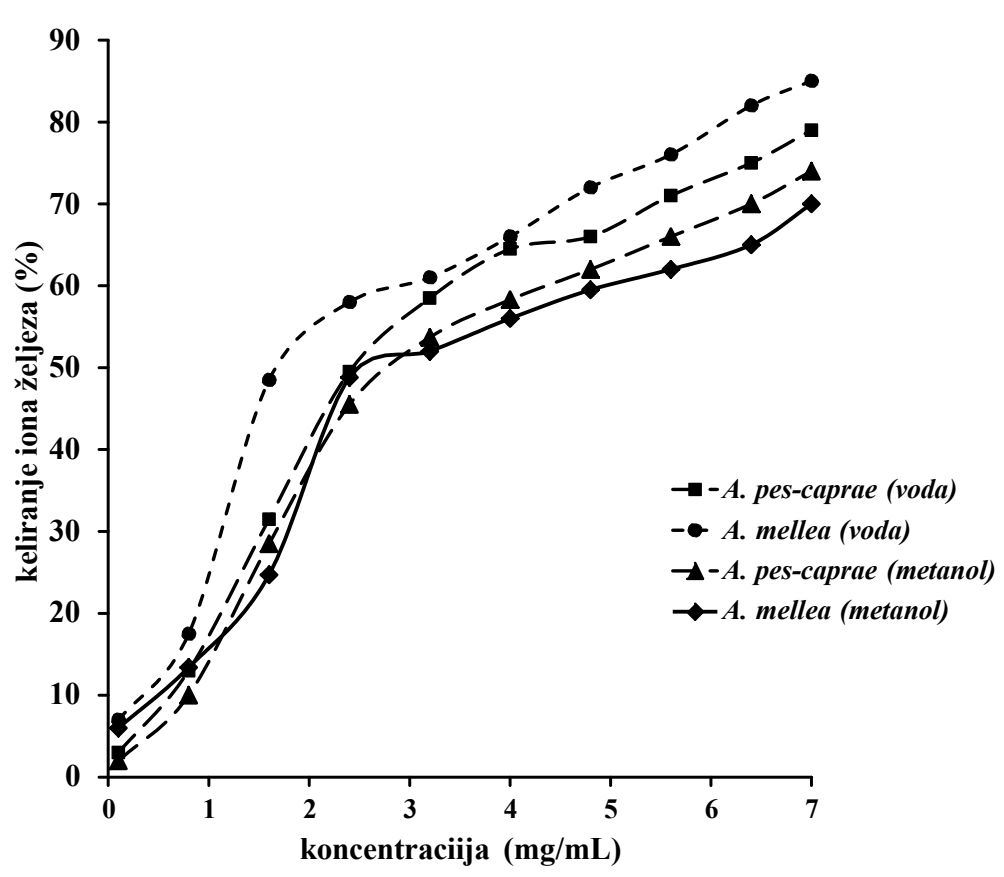

Grafikon 3. Keliranje $\mathrm{Fe}^{2+}$ iona u vodenim i metanolnim ekstraktima plodišta A. pes-caprae i A. mellea

Graph. 3. Chelating effects of the A. pes-caprae and $A$. mellea fruit bodies water and methanolic extracts

Različiti antioksidacijski sastojci mogu djelovati in vivo putem različitih mehanizama, tako da se ne može tvrditi da se samo jednom metodom može u potpunosti evaluirati ukupni antioksidacijski kapacitet istraživanih uzoraka (Tsai i sur., 2007). Zbog tog su razloga u ovom radu korištena tri komplementarna test-sustava za ocjenu antioksidacijske aktivnosti ekstrakata gljiva. U ovom je radu antioksidacijska aktivnost ekstrakata gljiva provedena određivanjem reducirajuće snage i sposobnosti uklanjanja DPPH slobodnih radikala, te keliranja $\mathrm{Fe}^{2+}$ iona. Normalizirani rezultati istraživane antioksidacijskih aktivnosti različitim metodama, izraženi kao $\mathrm{EC}_{50}$ su prikazani u Tablici 5. Vidljivo je da su vodeni ekstrakti gljiva A. pes-caprae i A. mellea pokazali bolju antioksidaciijsku aktivnost od metanolnih ekstrakata, jer su, kod svih metoda, postignute niže $\mathrm{EC}_{50}$ vrijednosti. Činjenica da su vodeni ekstrakti pokazali bolju antioksidacijsku aktivnost od metanolnih može se objasniti značajno većom koncentracijom fenolnih spojeva, nego što je izmjerena u metanolnim ekstraktima (Tablica 2). 
Tablica 5. EC $_{50}$ vrijednosti antioksidacijske aktivnosti ekstrakata plodišta $A$. pes-caprae i $A$. mellea vrućom vodom i metanolom

Table 5. $\mathrm{EC}_{50}$ values of antioxidant activities for hot water and methanolic extracts of $A$. pescaprae i $A$. mellea fruit bodies

\begin{tabular}{lccc}
\hline \multirow{2}{*}{$\begin{array}{c}\text { Vrsta gljiva/ } \\
\text { Mushroom }\end{array}$} & \multicolumn{4}{c}{$\begin{array}{c}\mathrm{EC}_{50} \text { vrijednost } \\
\text { Reducirajuća snaga/ } \\
\text { Reducing power }\end{array}$} & $\begin{array}{c}\text { Uklanjanje DPPH radikala/ } \\
\text { DPPH radical scavenging }\end{array}$ & $\begin{array}{c}\text { Sposobnost keliranja iona } \\
\text { željeza/Chelating ability of } \\
\text { ferous ions }\end{array}$ \\
\cline { 2 - 4 } A. pes-caprae & 2,67 & Vruća voda/Hot water & \\
\hline A. mellea & 1,63 & 6,81 & 2,42 \\
\hline A. pes-caprae & & 5,6 & 1,65 \\
\hline A. mellea & 3,33 & Metanol/Methanol & 2,98 \\
\hline
\end{tabular}

${ }^{a} \mathrm{EC}_{50}$ vrijednost: koncentracija pri kojojje izmjerena apsorbancija za reducirajuću snagu bila 0,5, a uklanjanje DPPH radikala i sposobnost keliranja iona željeza su iznosile $50 \%$ izmjerene vrijednosti. $\mathrm{EC}_{50}$ vrijednosti su dobivene interpolacijom rezultata linearnom regresijom.

${ }^{a} \mathrm{EC}_{50}$ value: the effective concentration at which the absorbance was 0.5 for reducing capability, DPPH radicals were scavenged by $50 \%$, ferrous ions were chelated by $50 \%$ EC $_{50}$ values were obtained by interpolation from linear regression analysis.

\section{Zaključak}

Prema dobivenim rezultatima, vodeni i metanolni ekstrakti plodišta gljiva A. pes-caprae i A. mellea sadrže vrlo korisne fitokemikalije, kao što su fenolni spojevi, askorbinska kiselina i karotenoidi. Kombinacija njihovih bioaktivnih spojeva i poželjnog kemijskog sastava (visokog udjela proteina i ugljikohidrata, te niskog udjela masti), čini ove istraživane vrste gljiva nutritivno vrijednim namirnicama. Također su, prema određivanjima reducirajuće snage, uklanjanja DPPH slobodnih radikala i keliranja iona željeza, ekstrakti pokazali vrlo dobru antioksidacijsku aktivnost. Vodeni su se ekstrakti, prema svim dobivenim rezultatima, pokazali učinkovitiji od metanolnih ekstrakata. Rezultati su pokazali da su ekstrakti istraživanih gljiva potencijalni izvori prirodnih antioksidanta, te da konzumacijom gljiva možemo doprinijeti zaštiti zdravlja organizma protiv oksidacijskih oštećenja. Uz dokazanu antioksidacijsku aktivnost, ekstrakti plodišta gljiva $A$. pes-caprae i $A$. mellea imali su izvrstan kemijski sastav, odnosno visoku nutritivnu vrijednost, te se mogu preporučiti kao sastojci funkcionalne hrane. Ovo istraživanje doprinosi ne samo boljem poznavanju nutritivne vrijednosti gljiva, nego i njihovoj sveobuhvatnoj valorizaciji.

\section{Literatura}

Agrahar-Murugkar, D., Subbulakshmi, G. (2005) Nutritional value of edible wild mushrooms collected from the Khasi hills of Meghalaya. Food Chemistry 89, 599-603. DOI: 10.1016/j.foodchem.2004.03.042

Alvarez, R., Enriquez, A. (1988) Nucleic acid reduction in yeast. Applied Microbiology and Biotechnology 29, $208-210$.

AOAC (2012) Offi methods of analysis of AOAC International (19. izd.).Gaithersburg, MD.USA: AOAC International

Barros, L., Baptista, P., Correia, D. M., Casal, S., Oliveira, B., Ferreira, I. C. F. R. (2007a) Fatty acid and sugar compositions, and nutritional value of fi e wild edible mushrooms from Northeast Portugal. Food Chemistry, 105, 140-145. DOI: 10.1016/j.foodchem.2007.03.052

Barros, L., Baptista, P., Estevinho, L. M., Ferreira, I. C. F. R. (2007b) Effect of fruiting body maturity stage on chemical composition and antimicrobial activity of Lactarius sp. mushrooms. Journal of Agricultural and Food Chemistry, 55, 87668771. DOI: $10.1021 /$ jf071435 
Barros, L., Venturini, B. A., Baptista, P., Estevinho, L. E., Ferreira, I. C. F. R. (2008a) Chemical composition and biological properties of Portuguese wild mushrooms: a comprehensive study. Journal of Agricultural and Food Chemistry, 56, 3856-3862. DOI: 10.1021/jf8003114

Barros, L., Cruz, T., Baptista, P., Estevinho, L. E., Ferreira, I. C. F. R. (2008b) Wild and commercial mushrooms as source of nutrients and nutraceuticals. Food and Chemical Toxicology, 46, 2742-2747. DOI: 10.1021/jfct.2008.04.030

Bobek, P., Galbavy, S. (1999) Hypocholesterolemic and antiatherogenic effect of oyster mushroom (Pleurotus ostreatus) in rabbit. Nahrung, 43, 339-342.

Caprioli, G., Lupidi, G., Maggi, F. (2019) Comparison of chemical composition and antioxidant activities of two Winter savory subspecies (Satureja montana subsp. variegata and Satureja montana subsp. montana) cultivated in Northern Italy. Natural Product Research, 33, 3143-3147. DOI: 10.1080/14786419.2018.1516661 476.

Chang, S. T., Buswell, J. A. (1996) Mushroom Nutriceuticals. World Journal of Microbiology and Biotechnology, 12, 473-

Cheung, L. M., Cheung, P. C. K., Ooi V. E. C. (2003) Antioxidant activity and total phenolic of edible mushroom extracts. Food Chemistry, 81, 249-255. DOI: 10.1016/50308-8146(2)00419-3

Colak, A., Faiz, Ö., Sesli, E. (2009) Nutritional composition of some wild edible mushrooms. Turkish Journal of Biochemistry, 34, 25-31.

Dikeman, C. L., Bauer, L. L., Flickinger, E. A., Fahey, G. C. Jr. (2005) Effects of stage of maturity and cooking on the chemical composition of selected mushroom varieties. Journal of Agricultural and Food Chemistry 53, 1130-1138. DOI: 10.1021/jf.0485411

Ferreira, I.C.F.R., Vaz, J.A., Vasconcelos, M. H. Martins, A. (2010) Compounds from wild mushrooms with antitumor potential. Anti-Cancer Agents in Medicinal Chemistry, 10, 424-436. DOI:

Gulçin, Y., Buyukokuroglu, M. E., Oktay, M., Kufrevioglu, O. Y. (2003) Antioxidanr and analgesic activities of terpentine of Pinus nigra. Journal of Ethnopharmacology, 86, 51-58. DOI: 10.1016/50378-8741/(03)00036-9

Huang, L.-C. (2006) Antioxidant properties of methanolic extracts from Agrocybe cylindracea. LWT, 39, 378-386. DOI: 10.1016/j.lwt.2005.02012

Jayakumar, T., Thomas, P. A., Sheu, J. R., Geraldine, P. (2011) In-vitro and in-vivo antioxidant effects of the oyster mushroom Pleurotus ostreatus. Food Research International, 44, 851-861. DOI: 10.1016/j.foodres.2011.03.015

Kalač, P. (2009) Chemical composition and nutritive value of European species of wild growing mushrooms: A review. Food Chemistry, 113, 9-16. DOI: 10.1016/j.foodchem.2008.07.077

Kaur, C., Kapoor, H. C. (2001) Antioxidant in fruit and vegetables-the milleniums health. International Journal of Food Science and Technology, 36, 703-725. DOI: 10.1111/j.1365-2621.2001.00513.x

Lee, Y.-L., Jian, S.-Y., Lian, P.-Y., Mau, J.-L. (2008) Antioxidant properties of extract from a white mutant of the mushroom Hypsizigis marmoreus. Journal of Food Composition and Analysis, 21, 116-124. DOI: 10.1016/j.jfca.2007.09.005

Léon-Guzmán, M. F., Silva, I., López, M. G. (1997) Proximate chemical composition, free amino acid contents, and free fatty acids contents of some wild edible mushrooms from Queretaro, México. Journal of Agricultural and Food Chemistry, 89, 533-539.

Mattila, P. K., Konko, M., Eurola, J., Pihlava, J., Astola, L., Vahteristo, V., Hietaniemi, J., Kumpulainen, N., Valtonen, V., Piironen, V. (2001) Contents of vitamins, mineral elements and some phenolic compounds in the cultivated mushrooms. Journal of Agricultural and Food Chemistry, 49, 2343-2348. DOI: 10.1021/jf001525d

Mau, J.-L., Lin, H.-C., Chen, C.-C. (2002a) Antioxidant properties of several medicinal mushrooms. Journal of Agricultural and Food Chemistry, 50, 6072-6077. DOI: 10.1021/jf0201273

Mau, J.-L., Lin, H.-C., Song, S.-F. (2002b) Antioxidant properties of several specialty mushrooms. Food Research International, 35, 519-526. DOI: 10.1016/50963-9969(1)00150-8

Mau, J.-L., Tsai, S.-Y., Tseng, Y.-H., Huang, S.-J. (2005) Antioxidant properties of hot water extracts from Ganoderma tsugae Murrill. LWT, 38, 589-597. DOI: 10.1016/j.Iwt.2005.02012

Ouzouni, P. K., Petridis, D., Koller, W.-D., Riganakos, K. A. (2009) Nutritional value and metal content of wild edible mushrooms collected from West Macedonia and Epirus, Greece. Food Chemistry, 115, 1575-1580. DOI: 10.1016/j.foodchem.2009.02.014

Oyetayo, V. O. (2009) Free radical scavenging and antimicrobial properties of extracts of wild mushrooms. Brazilian Journal of Microbiology, 40, 380-386. DOI: 10.1590/S1517-838220090002000031

Pereira E., Barros L., Martins A., Ferreira I.C.F.R. (2012) Towards chemical and nutrition of Portuguese wild edible mushrooms in different habitats. Food Chemistry, 130 (2), 394-403. DOI: 10.1016/j.foodchem.2011.07.057:

Puttaraju, N. G., Venkateshaiah, S. U., Dharmcoh, S. M., Urs, S. M., Somasundaram, R. (2006) Antioxidant activity of indigenous edible mushrooms. Journal of Agricultural and Food Chemistry, 54, 9764-9772. DOI: 10.1021/jf0615707

Sarikurkcu, C., Tepe, B., Yamac, M. (2008) Evaluation of the antioxidant activity of four edible mushrooms from the Central Anatolia, Eskisehir - Turkey: Lactarius deterrimus, Suillus collitinus, Boletus edulis, Xerocomus Chrysenteron. Bioresource Technology, 99, 6651-6655. DOI: 10.1016/j.biortech.2007.11.062

Soares, A. A., Souza, C. G. M., Daniel, F. M., Ferrari, G. P., Costa, S. M. G., Peralta, R. M. (2009) Antioxidant activity and phenolic content of Agaricus brasiliensis (Agaricus blazei Murrill) in teo stages of maturity. Food Chemistry, 112, $775-781$. DOI: 10.1016/j.foodchem.2008.05.117

Valentão, P., Lopes, G., Valente, M., Barbosa, P., Andrade, P., Silva, B., Baptista, P., Seabra, R. (2005) Quantitation of Nine Organic Acids in Wild Mushrooms. Journal of Agricultural and Food Chemistry,. 53. 3626-3630. DOI: 10.1021/jf040465z

Vaz, J. A., Barros, L., Martins, A., Santos-Buelga, C., Vasconcelos, M. H., Ferreira, J. C. F. R. (2011) Chemical composition of wild edible mushrooms and antioxidant proprties of water soluble polysaccharidic and ethanolic fractions. Food Chemistry, 126, 610-616. DOI: 10.1016/j.foodchem.2010.11.063

Tsai, S.-Y.,Tsai, H.-L., Mau, J.-L. (2007) Antioxidant properties of Agaricus blazei, Agrocybe cylindracea, and Boletus edulis. LWT-Food Science and Technology, 40, 1392-1402. DOI: 10.1016/j.Iwt.2006.10.001

Tsai, S.-Y., Huang, S.-J., Lo, S.-J., Wu, T..-P., Lian, P.-Y-. Mau, J.-L. (2009) Flavour components and antioxidant properties of several cultivated mushrooms. Food Chemistry, 113, 578-584. DOI: 10.1016/j.foodchem.2008.08.034 
Turkoglu, A., Duru, M.E., Mercan, N., Kivrak, I., Gezer, K. (2007) Antioxidant and antimicrobial activities of Laetiporus sulphureus (Bull.) Murrill. Food Chemistry, 101, 267-273. DOI: 10.1016/j.foodchem.2006.01.025

Wong, J. Y., Chye, F. Y. (2009) Abtioxidant properties of selected tropical wild edible mushrooms. Journal of Food Composition and Analysis, 22(4), 269-277. DOI: 10.1016/jfca.2008.11.021

Prispjelo/Received:11.9.2020.

Prihvaćeno/Accepted: 29.10.2020.

Original scientific paper

\title{
Nutritive value and antioxidant activity of wild edible mushroms Albarellus per-caprae and Armilaria mellea
}

\begin{abstract}
This study is designed for the determination of proximate chemical composition, contents of bioactive compounds, and antioxidant activity of wild edible mushrooms Albarellus per-caprae and Armilaria mellea. The obtained results of chemical composition revealed that the mushrooms were rich source of proteins and carbohydrates, low in fat content, and provides a good source of energy. Concentrations of five bioactive compounds (ascorbic acid, b-carotene, lykopene, total phenols, and flavonoids) are determined in hot water and methanolic extracts of mushrooms fruit bodies. Three complementary chemical assays: reducing power, free radical scavenging (DPPH), and chelating ability for ferrous ions were used to screen the antioxidant properties of extracts. The highest antioxidant capacity values were found for hot water extracts of $A$. mellea (9.01 $\mathrm{MM} \mathrm{TE/g} \mathrm{d.w.} \mathrm{in} \mathrm{reducing} \mathrm{power,} \mathrm{65 \%} \mathrm{in} \mathrm{scavenging} \mathrm{ability,} \mathrm{and} 85 \%$ in chelating ability). EC50 values for three different antioxidant assays were between $1.63 \mathrm{mg} / \mathrm{mL}$ to $6.86 \mathrm{mg} / \mathrm{mL}$. Due to these characteristics, wild edible mushrooms A. per-caprae and A. mellea could be used in well-balanced diets and as a source of bioactive compounds.

Keywords: Albarellus per-caprae, Armilaria mellea, Nutritive value, Bioactive compounds, Antioxidant activity
\end{abstract}

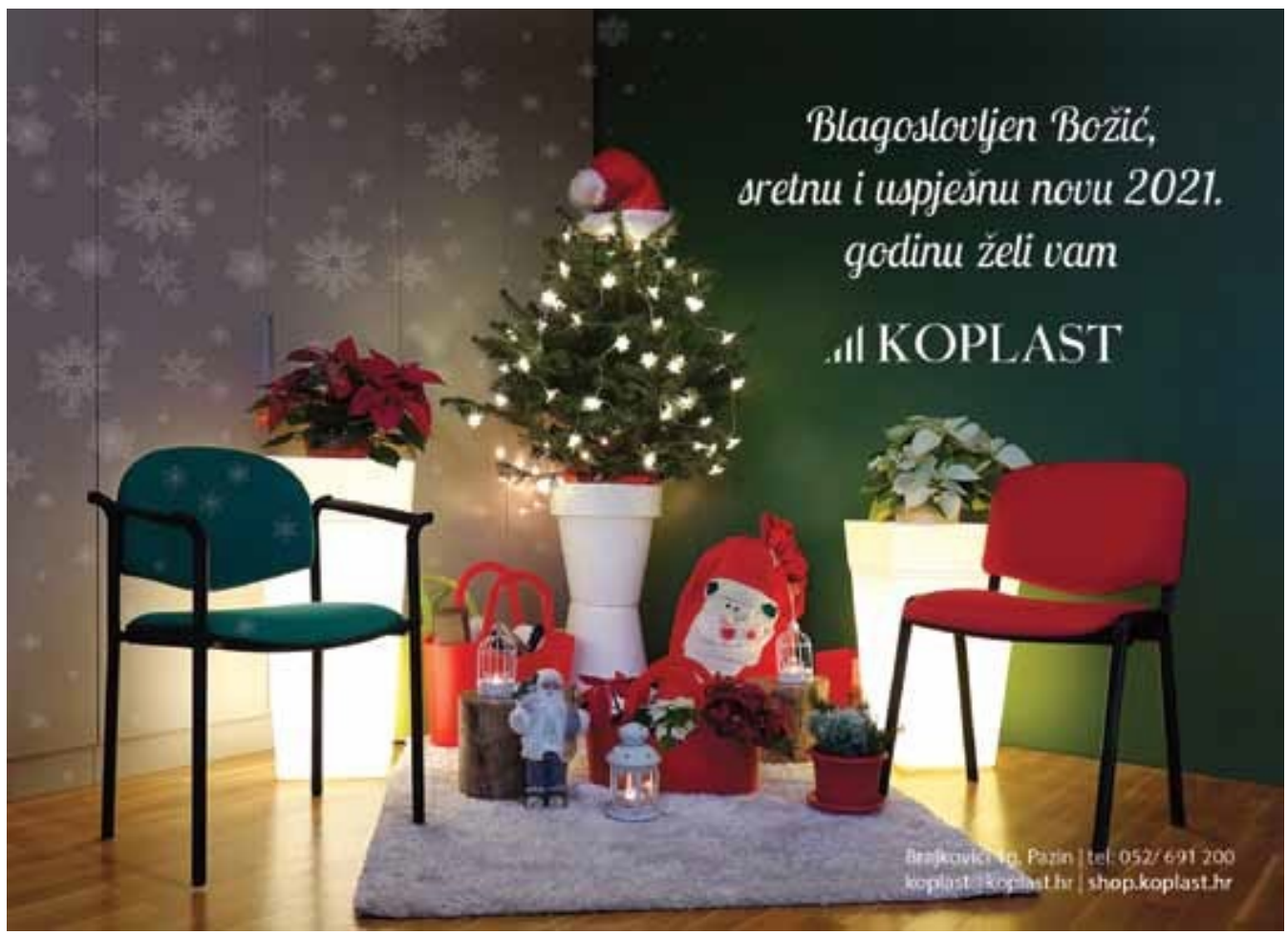

